\title{
THE ESSENTIALITY OF THE NUSANTARA TRADITIONAL CALENDAR
}

\author{
Hikmatul Adhiyah Syam \\ Astronom Mahasiswa Islam Sultan Alauddin Makassar \\ hikmaadhiyah.ha@gmail.com
}

\begin{abstract}
Today, tomorrow, yesterday, and later is the time because this life will always talk about the time that can affect the pattern of life in an environment. So that the existence of time becomes important. Based on this, a time system was compiled using the circulation of celestial bodies. Previous people have inherited the traditional calendar in their respective regions. This adapts to the condition of the community and its environment. The research question in this research is how the interpretations of the traditional calendars in the archipelago. The purpose of this research is to explore the essential meaning of the traditional calendars in the archipelago. The method used in this research is library research. This method is used to describe the various existing sources. The results showed that the calendar in each region has its own meaning for the wearer. The Batak calendar is used to determine good and bad days, the Pranatamangsa calendar for season markers, the Saka calendar for marking religious rituals, the Islamic Javanese calendar for historical momentum markers and Islamic teachings, the Bugis calendar for guidelines for daily activities and the Maluku calendar for marking the time of manufacture boat.

Keywords: Calendar, Traditional, Archipelago, Calendar, Meaning.
\end{abstract}

\begin{abstract}
Abstrak
Hari ini, besok, kemarin, dan nanti adalah waktu karena, hidup ini akan selalu berbicara tentang waktu yang dapat mempengaruhi pola hidup dalam suatu lingkungan sehingga keberadaan waktu menjadi penting. Berdasarkan hal tersebut, disusunlah sistem waktu menggunakan peredaran benda langit. Orang-orang terdahulu mempunyai warisan penanggalan tradisional di masing-masing wilayahnya dengan menyesuaikan kondisi masyarakat beserta lingkungan. Pokok permasalahan dalam penelitian ini adalah bagaimana pemaknaan ragam penanggalan tradisonal yang ada di Nusantara.Tujuan dari penelitian ini adalah menggali pemaknaan esensial dari penanggalan tradisional yang ada di Nusantara. Metode yang digunakan dalam penelitian ini adalah library reasearch untuk menguraikan berbagai sumber yang ada. Hasil penelitian menunjukkan bahwa penanggalan atau kalender di masing-masing wilayah mempunyai makna tersendiri bagi pemakainya. Kalender Batak di pakai untuk menentukan hari baik dan
\end{abstract}


buruk, kalender Pranatamangsa untuk penanda musim, kalender saka untuk penanda ritual keagamaan, kalender jawa islam untuk penanda momentum sejarah dan ajaran islam, kalender bugis untuk pedoman aktifitas sehari-hari dan kalender Maluku untuk penanda waktu pembuatan perahu.

Keywords: Penanggalan, Tradisional, Nusantara, Kalender, Makna.

\section{A. Introduction}

The existence of celestial objects (sun, moon, and stars) in their circulation has its own function for human life. One of them is to make it easier for humans to determine time. In life, time is a human benchmark in carrying out an activity. Based on this reality, the alternation and repetition of time make humans create a form of notation marked by numbers in a specific unit. This is usually called a calendar. ${ }^{1}$

The calendar has specific systems and rules based on the habits and understanding of a group of people. During its development, the calendar system, with celestial bodies as a reference, is divided into three, namely: (1) the sun: the Gregorian calendar, (2) the month: the Hijri calendar, and (3) the sun and the moon: the Chinese calendar, which has been widely found in literature and scientific discussion and is still in use today. Meanwhile, the timing system in Indonesia, which is divided into several islands with a variety of ethnicities, races, and cultures, has made the calendar system unique, special, and influential in the lives of previous societies. Knowledge about this calendar system is usually applied directly and then becomes the habit that is guided by the community. Besides, there is also a calendar system written in scripts used in carrying out daily activities. The existence of knowledge and manuscripts is what needs to be known and preserved as relics of the ancestors.

Previous studies related to the calendar are pretty varied. Some examine the relevance of one calendar with other calendars as has been done by Faiz Farichah. ${ }^{2}$ Some study the accuracy of the calendar from an astronomical perspective as a study of ayyamul bidh by Lua'yyin and M. Ihtirozun Ni'am ${ }^{3}$. Then about the accuracy of the date of birth and date of death of the Prophet Muhammad SAW by Anisah Budiwati ${ }^{4}$. Then, the corrections to the date of the death of Umar bin Khattab by Akhmad Nadirin and M. Ihtirozun Ni'am ${ }^{5}$. Besides, literature related to the Nusantara calendar system can be found in the book "Ethno-Archeo Astronomy" written by

1Sakirman Melacak and Konstruksi Metodologi, "Sakirman Melacak Konstruksi Metodologi...” 4, no. 01 (2015): 157-83.

${ }^{2}$ Faiz Farichah, "The Java Calendar and Its Relevance with The Islamic Calendar," Al-Hilal:Journal of Islamic Astronomy 2 (2020): 77.

${ }^{3}$ Lu'ayyin and M. Ihtirozun Ni'am, “Ayyam Al-Bid Syar'i and Astronomy Perspective,” Al-Hilal:Journal of Islamic Astronomy 2 (2020): 111.

${ }^{4}$ Anisah Budiwati, "Historical Astronomic Provision of Birth and Death Prophet Muhammad SAW," AlHilal:Journal of Islamic Astronomy 1 (2019): 1.

5 Akhmad Nadirin and M. Ihtirozun Ni'am, "Date Correction of Omar Bin Khattab's Death in an Astronomical Perspective," Al-Hilal:Journal of Islamic Astronomy 1 (2019): 87. 
Arwin Juli Rakhmadi Butar-Butar, "Bugis Navigation" written by Gene Ammarell, and the thesis "Islamic Javanese Calendar" written by Maulana Yusuf.

\section{B. Method}

The method used by the writer in this research is library research with a qualitative approach. The author collects data from primary sources or related literature then analyzes and discusses it from the point of view that the author adopts in this study.

\section{Discussion and Result}

According to the Big Indonesian Dictionary, the calendar is derived from the word date, which means a number that states which day in the month, while the word calendar itself means: (1) list of days of the month, almanac, takwim, calendar, (2) the affixing of the date, (3) ) tarikh. ${ }^{6}$ The term calendar originates from the Latin "kalendarium" which comes from "kalendae" or "calendae" which means the day of the beginning of a month. ${ }^{7}$ In classical-contemporary literature, the calendar is called tarikh, takwim, almanak, and calendar. ${ }^{8}$ Allah swt said that celestial bodies can be used as a timepiece for humans in Qs. Yunus/10:5,

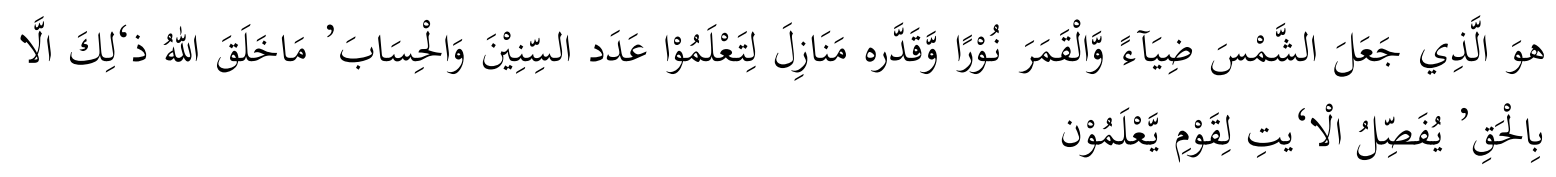

Translation:

He is the One who made the sun a radiant source and the moon a reflected light, with precisely ordained phases, so that you may know the number of years and calculation 'of time'. Allah did not create all this except for a purpose. He makes the signs clear for people of knowledge. ${ }^{9}$

There is a classification system based on the development of the world from ancient to modern times, namely: the Primitive, Western, Chinese, Egyptian, Indian, Babylonian, Jewish, Greek, Islamic, and Central American calendar systems. The difference in the calendar system is based on three major groups of the calendar system, namely, (1) solar calendar: based on the solar cycle, (2)lunar calendar: based on the lunar cycle, and (3) lunisolar calendar: based on the moonsun cycle. ${ }^{10}$ In Indonesia, there are several calendar systems:

${ }^{6}$ Departemen Pendidikan Nasional, "Kamus Besar Bahasa Inddonesia Pusat Bahasa," in KBBI, ed. Dendy Sugono, IV (Jakarta: PT Gramedia Pustaka Utama, 2011), 1396. n.d., $1-15$.

7Pemikiran Mohammad Ilyas et al.,"PEMIKIRAN MOHAMMAD ILYAS TENTANG PENYATUAN,"

${ }^{8}$ Siti Nur Halimah, “Al-Marshad: Jurnal Astronomi Islam Dan Ilmu-Ilmu Berkaitan,” Jurnal Astronomi Islam Dan Ilmu-Ilmu Berkaitan 4, no. 1 June (2018): 11, https://media.neliti.com/media/publications/268350. penanggalan-mesir-kuno-61e38fac.pdf.

${ }^{9}$ Khadim Al Haramain Asy Syarifain, Al-Quran Dan Terjemahnya (Jakarta, 1971).

${ }^{10}$ Alaik Ridhallah, "Sistem Penaggalan Baha i Persfektif Astronomi," AL-AFAQ Jurnal Ilmu Falak Dan Astronomi 2, no. 1 (2020): 53-88. 


\section{Batak Calendar}

Parhalaan is a term in Batak language, which means calendar. Parhalaan comes from the word hala, which means scorpion, which is a vicious animal. ${ }^{11}$ It can also be interpreted that Scorpio is the constellation used by the Batak community in this parhalaan system.

The Batak calendar system has a slightly different meaning and function from the calendar use in general. This is because the Batak community explicitly uses parhalaan to determine good and bad days in carrying out daily activities. This determination is based on predictions related to the conditions of circulation of celestial bodies such as the moon, sun and stars. Based on this, parhalaan is better known as pustaha (collection of Batak knowledge) which contains guidelines for the Batak ancestors (datu) who predict. So that in practice, the community makes ancestors as parties who can answer and provide solutions when carrying out a job.

Batak calendar system based on the month. The number of days in a month is 30 days, the number of days in a week is 7 days, and the number of months in a year is 12 months. If it consists of 13 months, it is suspected to be an intercalation settlement to adjust the Hijriyyah year to the Masihi year. Meanwhile, the number of days in a year is 360 days. The interesting thing about this Batak calendar system is that the number of days in a month is not counted in numerical order but has its names.

The names of the days in the Batak calendar are: artia, suma, anggara, muda, boraspat, singkora, samisara, antian ni aek, suma ni mangadop, anggara sampulu, muda ni mangadop, boraspati ni tangkop, boraspati tinangkop, singkora purnama, samisara purnama, tula, suma ni holom, boraspati ni holom, singkora mora turun, singkora dua pulu, samisara mora turun, antian ni angga, antian ni anggara, suma ni mate, anggara na begu, anggara ni begu, muda ni mate, boraspati ni gok, singkora duduk, samisara bulan mate, hurung, ringkar. Meanwhile, the names of the months in the Batak (Toba) calendar are sipahasada, sipahadua, sipahatolu, sipahaopat, sipahalima, sipahaonom, sipahapitu, sipahauala, sipahasia, sipahasampulu, sipahasampulusada, dan sipahasampuludua, if there is a 13th month it is called lobi-lobi or lamadu. ${ }^{12}$

Parhalaan designs are very rarely found in the form of writing. Usually the media used by the Batak community are bamboo and bark of various sizes.

\footnotetext{
${ }^{11}$ Arwin Juli Rakhmadi Butar-Butar, Astronomi (Surabaya: Media Sahabat Cendekia, 2019)., h. 34.

${ }^{12}$ Butar-Butar., h. 34-36.
} 


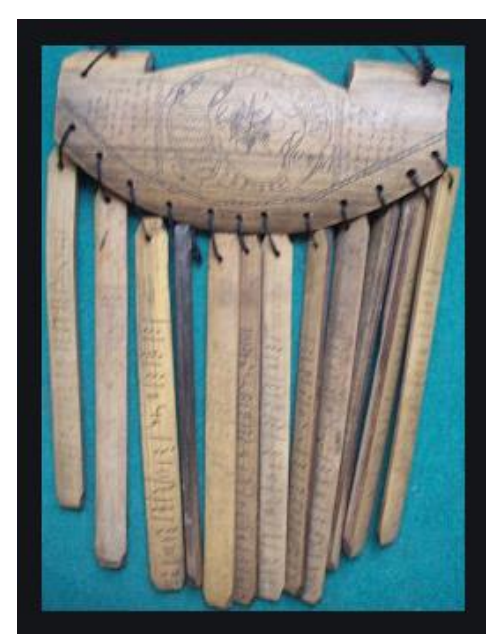

Picture 1. Parhalaan

https://www.google.com/url?sa=i\&url=http\%3A\%2F\%2Fdokuliah.blogspot.com\%2F2016\%2F03\%2 Fpenanggalan-dan-kalenderparhalaan.html\&psig=AOvVaw2R7yHTg_NECOyb5ENf7bBR\&ust=1617647110485000\&source=images\&cd =vfe\&ved=2ahUKEwjIqLScm-XvAhXQGHIKHectBF8QjRx6BAgAEAc

The parhalaan design consists of 12 sections of bamboo representing 12 months. There are also 13 months which are called lobbying months or lamadu. This 13th month occurs because the lunar system (Kamariyah) cannot be used for agricultural purposes. So it is necessary to add one more month to match the duration of the earth's journey around the sun, 365 days.

There is a kala image containing three to four days as a sign of bad days, which the public believes and is very much avoided on each section. In practice, the first day of each month usually falls on the dead moon (the hilal phase), and the full moon falls on the fourteenth day. The beginning of the year is determined when the constellation Scorpio (siala poriama) is on the eastern horizon and the Orion constellation (siala sungsang) sinks in the western horizon which coincides in May. If a thin crescent is visible before sunset in the north of Orion before the western horizon, then it is the start of a new year in the Batak calendar. Fourteen days later the full moon rises on the eastern horizon and takes a position north of the constellation Scorpio. ${ }^{13}$

Currently, Parmalim, as a belief based on the religion of the Batak ancestors which is the Batak Community, still uses parhalaan. It is said that in the Karo area until now they still integrate the Masihi calendar and the Batak calendar.

2. Jawa Calender

The calendar system that developed in Javanese society is divided into two periods with three types of calendar systems. The first period is the pre-Islamic period. There are two calendar

${ }^{13}$ Butar-Butar., h. 35-36. 
systems, namely the Pranatamangsa (marking the seasons) and the Saka calendar (based on the Hindu calendar). Meanwhile, the second period, which is the period after Islam, was present in Java as the Islamic Javanese calendar (related to the Hijriyyah calendar).

\section{a. Pranatamangsa Calender}

Pranatamangsa is a traditional calendar of season rules that farming communities in Java have long recognized. Pranatamangsa calendar is taken from the word "mangsa" which means season, while "pranata" means provision. So that Pranatamangsa is a time or season rule that is used as a farming guide for farmers based on the Syamsiyah calendar, ${ }^{14}$ pseudo circulation solar calendar based.

The Pranatamangsa calendar is a legacy from the ancestors of the Javanese people. The calendar is a guide in doing work or farming activities to meet daily needs. The Javanese owned this calendar system before the arrival of Hinduism on the island of Java. Based on this, the existence of the Pranatamangsa calendar is a pure calendar system originating from the Javanese society without any outside influence. Apart from the sun, Pranatamangsa also made the stars as celestial bodies, which underlies knowledge about the repetition of the seasons. So this system also applies to fishers who use stars as a benchmark when going to sea. ${ }^{15}$

The motion of the earth evolves around the sun resulting in different seasonal changes and the appearance of different constellations. Physically, the changes in the seasons on earth with the appearance of the constellations have nothing to do with it. This is because of the great distance between the stars and the earth. However, because the appearance of their position is relatively constant in each season, certain stars are used as indicators of the season. In many libraries on Pranatamangsa, the indicator stars are written with traditional names, for example: Sapi Gumarang, Tagih, Lumbung, Jaran Dawuk, Banyak Angrem, Gotong Mayit, Bima Sakti, Wulanjar Ngirim, Wuluh, Waluku, Tagih, Guru Tani, Gubuk Penceng, Klopo Doyong, Sangkal Putung, and many more, but the position of the appearance and the name of the constellation is not explained internationally. ${ }^{16}$

At first the Pranatamangsa calendar began to be associated with the Gregorian calendar. This started when Sri Paduka Susuhunan Paku Buwono VII had a desire to provide certainty to his people who were confused by the many calendar systems (Saka,

${ }^{14}$ Ahmad Mustaid,"Analisis Penanggalan Jawa Pranata Mangsa Terhadap Sirkulasi Monsun Dalam Perspektif Klimatologi”(UIN Walisongo Semarang, 2019).

${ }^{15} J u r n a l$ Pemikiran and Hukum Islam, "Al-Mizan" 13, no. 1 (2017): 53-68.

${ }^{16}$ Supardiyono Sobirin, "Pranata Mangsa Dan Budaya Kearifan Lingkungan,” Jurnal Budaya Nusantara 2, no. 1 (2018): 250-64, https://doi.org/10.36456/b.nusantara.vol2.no1.a1719. 
Pawukon, Pranatamangsa, Hijriah, and Gregorian). At that time, Pranatamangsa is expected to be the right solution to find out when a season starts and ends. In addition, it is also to find out what needs to be done in agricultural activities.

Initially Pranatamangsa only had 10 mangsa. After the tenth mangsa, which is April 18, people wait for the start of the first mangsa (Kasa and Kartika), which is June 22. The waiting period was long enough that the eleventh mangsa (Destha and Padrawana) and the twelfth prey (Sadha or Asuji) were applied. Then it is even one year to become 12 prey. Commencement of the first day of the first mangsa is on June 22 and goes along with the Saka calendar.

Table 1. 12 Mangsa Periods in One Year

\begin{tabular}{ccc}
\hline Mangsa & Period & Amount \\
\hline Kasa (Kartika) & 22 June-1 August & 41 Day \\
\hline Karo (Pusa) & 2 August - 24 August & 23 Day \\
\hline Katiga (Katelu) & 25 August - 17 September & 24 Day \\
\hline Kapat (Sitra) & 18 September - 12 October & 25 Day \\
\hline Kalima (Manggala) & 13 October - 8 November & 27 Day \\
\hline Kanem (Naya) & 9 November - 21 December & 43 Day \\
\hline Kapitu (Palguna) & 22 December - 22 February & 43 Day \\
\hline Kawolu (Wasika) & 3 February - 28 February & 26/27 Day \\
\hline Kasanga (Jita) & 1 March - 25 March & 25 Day \\
\hline Kadasa (Srawana) & 26 March - 18 April & 24 Day \\
\hline Dhesta (Padrawana) & 29 April - 11 May & 23 Day \\
\hline Sadha (Asuji) & 12 May - 21 June & 41 Day \\
\hline
\end{tabular}

In addition, there are innate characteristics or the influence of three kinds of seasons as follows: 1) Kasa (Kartika), candra or the characteristic of Sotya Morca Ing Embanam (pearls are loose from the binding). Characteristics of the effects include: fallen leaves, broken wood above, starting to plant crops, grasshoppers lay eggs, and babies born this season have a compassionate character. 2) Karo (Pusa), candra or its characteristic is Bantala Rangka (cracked ground). Characteristics of the effects include: cracked soil, secondary crops must be watered, the season when the randu tree grows its 
leaves, and babies born in this season are careless and dirty in character. 3) Sadha (Asuji), which is characterized by Tirta Sasana (water leaves its place). Characteristics of the effects, among others: winter, people rarely sweat, the harvest is over, and babies born this season have sufficient character. ${ }^{17}$

The conditions for the development of the Pranatamangsa calendar, based on the history of the golden age to the fading of the Pranatamangsa, can be divided into five periods. The first period, around 1817, as told by Raffles (1817). Farmers have used the elements of Pranatamangsa for their agricultural activities. The second period, around 1855, when Sri Paduka Susuhunan Pakubuwono VII designated Pranatamangsa as the official agricultural calendar ${ }^{18}$. The third period, around 1920, was when climate anomalies became known. Farmers were waiting in vain for the rain to fall in the rainy season (the 1960s). ${ }^{19}$ The fourth period, around 1970 to 1990, when Pranatamangsa began to be neglected. Around 1997, Pranatamangsa was increasingly inaccurate because there were deviations from the pseudo circulation calculations of the sun. ${ }^{20}$

According to Didiek Wiriadiwangsa, the Javanese and Balinese call it Pranatamangsa (Sundanese), Pranotomongso (Java) and Kerta Masa (Bali). Our ancestors memorized patterns of seasons, climates, and other natural phenomena. Creating an annual calendar not based on the Syamsiah calendar or the Komariah calendar (Hijrah / Islam), but based on natural events, such as the rainy season, dry season, flowering season and the location of the stars in the universe, as well as the influence of the full moon on the ebb and flow of sea water. ${ }^{21}$

Table 2. 12 Pranatamangsa for a year

\begin{tabular}{ccc}
\hline Kasa $($ Kahiji $)$ & 22/23 June $-2 / 3$ August & $\begin{array}{c}\text { Palawija planting } \\
\text { season }\end{array}$ \\
\hline Karo $($ Kadua $)$ & 2/3 August $-25 / 26$ August & $\begin{array}{c}\text { Kapok Sprouts } \\
\text { Season, Second } \\
\text { Palawija Planting } \\
\text { Season }\end{array}$ \\
\hline Katiga $($ Katilu $)$ & 25/26 August $-18 / 19$ & $\begin{array}{c}\text { Tuber Sprouting } \\
\text { Season, Palawija } \\
\text { September }\end{array}$
\end{tabular}

${ }^{17}$ Pemikiran and Islam, "Al-Mizan.”

18 Sobirin, "Pranata Mangsa Dan Budaya Kearifan Lingkungan."

${ }^{19}$ Hastin Erma Yuli, "Mengapa Terjadi Kemarau Basah?," Membumi Mengangkasa, 2013, https://doi.org/https://yulihastin.wordpress.com/2013/07/03/mengapa-terjadi-musim-kemarau/.

${ }^{20}$ Sobirin, "Pranata Mangsa Dan Budaya Kearifan Lingkungan."

${ }^{21}$ Dedik Wiriadiwangsa, "Pranata Mangsa , Masih Penting Untuk Pertanian," n.d., 10-12.

Al-Hilal: Journal of Islamic Astronomy, Vol. 3, No. 1, 2021

p-ISSN : 2775-1236 ; e-ISSN : 2775-2119 


\begin{tabular}{|c|c|c|}
\hline Kapat (Kaopat) & $\begin{array}{c}\text { 18/19 September - 13/14 } \\
\text { October }\end{array}$ & $\begin{array}{c}\text { Dry Well Season, } \\
\text { Kapok produces } \\
\text { fruit, Planting } \\
\text { Bananas }\end{array}$ \\
\hline Kalima (Kalima) & $\begin{array}{c}\text { 13/14 October }-9 / 10 \\
\text { November }\end{array}$ & $\begin{array}{c}\text { Rainy Season, } \\
\text { Sprouting tamarind } \\
\text { trees, Young Leafy } \\
\text { Turmeric Trees }\end{array}$ \\
\hline Kanem (Kagenep) & $\begin{array}{c}9 / 10 \text { November }-22 / 23 \\
\text { December }\end{array}$ & $\begin{array}{c}\text { Fruit Season Begins } \\
\text { to Aging, Start } \\
\text { Working in the } \\
\text { Fields }\end{array}$ \\
\hline Kapitu (Katujuh) & $\begin{array}{l}\text { 22/23 December }-3 / 4 \\
\text { February }\end{array}$ & $\begin{array}{l}\text { Season of Flood, } \\
\text { Storm, Landslide, } \\
\text { Start Planting }\end{array}$ \\
\hline Kawolu (Kadalapan) & 2/3 February & $\begin{array}{c}\text { Rice Season, Many } \\
\text { Caterpillars, Many } \\
\text { Diseases }\end{array}$ \\
\hline Kasonga (Kasalapan) & 1/2 March - 26/27 March & $\begin{array}{l}\text { Flowering Rice } \\
\text { Season, Turaes } \\
\text { (Insect species) } \\
\text { Crowded Sounds }\end{array}$ \\
\hline Kadasa (Kasapuluh) & 26/27 March - 19/20 April & $\begin{array}{l}\text { Rice Season Fills but } \\
\text { Still Green, Birds } \\
\text { Make Nests, Plant } \\
\text { Palawija in Dry Land }\end{array}$ \\
\hline Desta (Kasabelas) & 19/20 April - 12/13 May & $\begin{array}{c}\text { There Is Time To } \\
\text { Plant Palawija, The } \\
\text { Birds Feed Their } \\
\text { Chicks }\end{array}$ \\
\hline Sada (Kaduabelas) & 12/13 April - 22/23 June & $\begin{array}{l}\text { Season of Stacking } \\
\text { Straw, Signs of the } \\
\text { Morning Cold }\end{array}$ \\
\hline
\end{tabular}

Other literature mentions that the ancient Javanese calendar existed before the entry of Hinduism-Buddhism. The Old Javanese calendar also has a time division system in a year like the Pranatamangsa. However, there are three differences in the Pranatamangsa and the Old Javanese calendar. First, the two seasons (division of time a year) in Pranatamangsa are called "Dhesta" while in Old Javanese it is called "Apit Lemah". In addition, in Pranatamangsa it is called "Sadha" while in Old Javanese it is "Apit Kayu". Second, the people of ancient Java also know the term "Sadrawa", a six-day cycle (a week consisting of six days: Aryang, Wurukung, Panigron Uwas, Wawulu, and Tungle) and 
"Pancawara" a five-day cycle (a week consisting of five days, that is: Pahing, Pon, Legi, Kliwon, dan Wage). ${ }^{22}$

Table 3. The Four Seasons of the Old Javanese Calendar in a Year

\begin{tabular}{ccc}
\hline Season & Meaning & Pranatamangsa \\
\hline Mareng & The Time When It Rains Less & $\begin{array}{c}\text { Kesepuluh, Apit Lemah, Apit } \\
\text { Kayu }\end{array}$ \\
\hline Ketigo & Summer and Dry Season & Koso, Karo, Ketigo \\
\hline Labuh & The Time When It Rains Often & Kapat, Kelimo, Kanem \\
\hline Rendheng & The Time When It Rained A Lot & Kapitu, Kawulo, Kesongo \\
\hline
\end{tabular}

b. Saka Calender

The Saka calendar is a calendar that originated in India. This calendar is a Syamsiyah Qamariyah calender (candra surya) or luni solar. Not only used by the Hindu community in India, the Saka calendar is also still used by the Hindu community in Bali, Indonesia, significantly to determine their religious holidays. ${ }^{23}$ On the island of Java, the Saka calendar system was once applied, a calendar system based on the sun's circulation around the Earth. The Saka calendar was used in Java until the early 17th century. ${ }^{24}$

The beginning of this Saka year is Saturday (March 14, 78 AD). Namely one year after the coronation of King Syaliwahono (Aji Soko) as the King of India. That is why this calendar is known as the Soko calendar. ${ }^{25}$ Some argue that the Saka calendar began in $78 \mathrm{AD}$, when the city of Ujjayini (Malwa in present-day India) was conquered by the Saka (Scythia) under the leadership of King Kaniska from the hands of the Satavhana. The new year occurs during the Minasamkranti (sun in the constellation Pisces) in early spring. Dipdjojo argued that the Saka calendar began with the birth of the King of Saka, named Caliwana. The incident occurred on March 1478 AD. Meanwhile, Damais argued that the beginning of the Saka calendar coincided on March 378 AD, 20/21

${ }^{22}$ Rufaidah, "Sistem Perhitungan Kalender Jawa Islam Dalam Kehidupan Masyarakat Desa Tunglur, Kec. Badas, Kab. Kediri” (UIN Sunan Amel, 2015)., h. 27-28.

${ }^{23}$ Pemikiran and Islam, "Al-Mizan."

${ }^{24}$ Susiknan Azhari and Ibnor Azli Ibrahim, "Kalender Jawa Islam: Memadukan Tradisi Dan Tuntutan Syari," Jurna Asy-Syirah 42, no. 1 (2008): 131-47.

${ }^{25}$ Pemikiran and Islam, "Al-Mizan." 
February 79 AD or 14 March 78 AD According to Darmosoetopo, the beginning of the Saka date coincided with Tuesday pahing wurukung (date March 10, 78M). ${ }^{26}$

Since 78 AD, the Saka calendar was established. One year of Saka calendar has 12 months. The first month is called Caitramasa or Srawanamasa. Apart from rearranging the calendar, religious, social and state life, society in India has also been restructured. So that the commemoration of the Saka New Year means a day of resurrection, renewal, togetherness (equality and unity), peace, tolerance, and a day of national harmony. Amount of days in the Saka year is 30, 31, 32, or 33 days in the last month, Saddha month, so the number of days in one year of the Saka calendar period is $365 / 366$ days divided into twelve months. ${ }^{27}$

Table 4. Name of Month in the Saka Calendar

\begin{tabular}{lcc}
\hline Name & Conversion & Amount \\
\hline Srawana & 12 July - 12 August & 32 \\
\hline Bhadra & 13 August - 10 September & 29 \\
\hline Asuji & 11 September - 11 October & 31 \\
\hline Kartika & 12 October - 10 Novemeber & 30 \\
\hline Posya & 11 November - 12 December & 32 \\
\hline Margasirsa & 13 December - 10 January & 29 \\
\hline Magha & 11 January - 11 February & 32 \\
\hline Phalguna & 12 February - 11 March & 29 \\
\hline Cetra & 12 March - 11 April & 31 \\
\hline Wesakha & 12 April - 11 May & 30 \\
\hline Jyesta & 12 May - 12 June & 32 \\
\hline Asadha & 13 June - 11 July & 29 \\
\hline & Total & 366 \\
\hline
\end{tabular}

${ }^{26}$ Iva Istiqamah, "Prasasti Masjid Agung Sunan Ampel Surabaya (Study Tentang Kontak Peradaban Antara Jawa, Arab Dan Barat Dalam Kronologi” (Sunan Ampel Surabaya, 2009)., h.6.

27Pemikiran and Islam,"Al-Mizan." 
The Saka calendar does not mention the date with numbers but with terms and only up to fifteen, then returns to the date by looking at the month's conditions. One month Saka experiences two conditions in the month, namely suklapaksa and krsnapaksa. Suklapaksa is a condition where the moon or parts of the moon appear bright. Krsnapaksa is the dark part of the moon. So the Saka calendar does not have the 16th.

The term date in the Saka calendar: Pratipada: 1, Dwitiya: 2, Tritiya: 3, Caturthi: 4, Pancami: 5, Sasti: 6, Saptami: 7, Stami: 8, Nawami: 9, Dacami: 10, Ekadici: 11, Dwadaci: 12, Trayodaci: 13, Caturdaci: 14, and Pandadaci: 15In the Saka calendar there is a sevenday cycle known as Saptamara. The pronunciation is generally abbreviated. The names of the days in the Saka calendar, namely, Aditya (A,Ra): Sunday, Soma (So): Monday, Anggara (Ang): Tuesday, Budha (Bu): Thursday, Wrhaspati (Wr): Wednesday, Cukra (Cu): Friday, dan Canaiscara (Ca): Saturday.

In calculating five dailies (pancawara) and six dailies (sadrawa) in Java, the Saka calendar is still used. Furthermore, added new knowledge obtained in the form of Pawukon. There are 30 weekly cycles in the Saka calendar. The cycle starts on Sundays, so that in one year wuku runs 210 days to return to the first wuku. The interaction between Java and India, which lasted for a long time, made the scientific transformation absorbed by the Javanese people in terms of the calendar, forming different local characteristics that gave birth to the Saka calendar system in the Javanese version.

c. Islamic Javanese Calender

After the arrival of Islam, the Saka calendar was replaced by the Javanese Islamic calendar which was first coined by Sultan Agung Ngabdurrahman Sayidin Panotogomo Molana Matarami (1613-1645) from Mataram. He is a Muslim with the Kejawen belief, which is an Islamic religion that has acculturated with the culture and beliefs of the Javanese people who were previously Hindu-Buddhist.

Islam carries the Hijri calendar which is based on the cycles of the moon. Then, Sultan Agung, with his creative ijtihad, integrated and preserved the two calendars with the traditions and demands of syar'i. ${ }^{28}$ The method is that the ongoing Saka year number is used as the initial benchmark for calculating this calendar, while the month's age refers to the Hijri calendar calculation system. The decision was agreed upon later, followed by Sultan Abdul Mafakhir Mahmud Abdul Kadir (1596-1651) from Banten. ${ }^{29}$

${ }^{28}$ Irma Rosalina, "Penyesuaian Kalender Saka Dengan Kalender Hijriyah Dan Aplikasinya Dalam Penentuan Awal Bulan Qomariah,” Fakultas Syariah UIN Maulana Malik Ibrahim Malang, November 19, 2013.

${ }^{29}$ Ahmad Syafii Mufadzilah, "Tarekat Dan Tradisi Lokal” (UIN Sunan Kalijaga, 2019). 
Thus, the Saka calendar system was no longer used and was replaced by the Javanese Islamic calendar.

There are similarities and differences in the Hijri calendar system and the Islamic Javanese calendar. The equation for these two calendars is a system that refers to the Moon's orbit when it orbits the Earth (Kamariyah). So that the Javanese Islamic calendar is also commonly referred to as the Canrasangkala Javanese calendar. Meanwhile, 1 year in the hijri calendar is 354 days 8 hours 48 minutes or $35411 / 30$ days, while the Javanese calendar is 354 days 9 hours or 354 3/8 days. The Javanese Islamic calendar stipulates that the change of day when the month changes in time is fixed, namely at sunset (between 17:00 - 18:00), while the change of day when the month's change in the Hijriyah calendar is determined through Hilal and rukyat. The difference between the hijriyah year and the Javanese year is 3 days apart. It is only a 1 day difference because according to the decree of the Kraton Solo, it has already been exceeded 2x1 days, namely in 1674 and 1748 Java. These two years are leap years defined as basithah years. Therefore, the difference between the Javanese year and the present hijriyah year is only 1 day apart. ${ }^{30}$

Table 5. The name of the Javanese year in one windu with Arabic numerology.

\begin{tabular}{cc}
\hline $\begin{array}{c}\text { Letters (Arabic } \\
\text { dialect) }\end{array}$ & $\begin{array}{c}\text { Letter (Javanese } \\
\text { dialect) }\end{array}$ \\
\hline Alif & Alip \\
\hline Ha & Ehe \\
\hline Jim Awwal & Jimawal \\
\hline Zai & Je \\
\hline Dal & Dal \\
\hline Ba & Be \\
\hline Waw & Wawu \\
\hline Jim Akhir & Jimakir \\
\hline
\end{tabular}

The name of the month in this calendar is based on the Hijri year. However, it still adjusts to the Javanese dialect and is given a name that is related to the moments that exist in that month.

${ }^{30}$ Ali Masud, "Penentuan Bulan Kamariah Menggunakan Sistem Aboge Dan Implementasinya" (IAIN Walisongo, 2014), http://eprints.walisongo.ac.id/id/eprint/2748. 
Table 6. Hijri year as a reference for the name of the month in the Javanese Islamic calendar

\begin{tabular}{ccc}
\hline Hijriyah & $\begin{array}{c}\text { Javanese } \\
\text { Islamic }\end{array}$ & Explanation \\
\hline Muharram & Suro & Because there is an Asyuro day \\
\hline Safar & Sapar & - \\
\hline Rabiul Awwal & Mulud & $\begin{array}{c}\text { Month of Birth of Prophet } \\
\text { Muhammad SAW }\end{array}$ \\
\hline Rabiul Akhir & Bakda Mulud & - \\
\hline Jumadl Uwla & Jumadil Awal & - \\
\hline $\begin{array}{c}\text { Jumadal } \\
\text { Akhir }\end{array}$ & Jumadiakir & \\
\hline Rajab & Rejeb & - \\
\hline Syaban & Ruwah & Javanese People Ordinary do Ruwatan \\
\hline Ramadan & Pasa & Fasting Month \\
\hline Syawwal & Sawal & A Month beetwen two holyday \\
\hline Dzulqodah & Selo/Hapit & Month of Performing Haji and Great \\
\hline Dzulhijjah & Haji/Besar &
\end{tabular}

Sultan Agung also replaced the names of the days in Sanskrit which are Hindu in style with the names of the days in Arabic which were adapted to the Javanese dialect and still preserve the pancawara day (Pahing, Pon, Wage, Kliwon, Legi/Manis) which is the original concept of Javanese society.

Table 7. Name of the Day in Sanskrit

\begin{tabular}{ccc}
\hline Sanskrit & Arabic & Javanese \\
\hline Raditya & Ahad & Ahad \\
\hline Soma & Isnain & Senen \\
\hline Anggara & Thulatha & Seloso \\
\hline Budha & Arbia & Rebo \\
\hline Brehaspati & Khamis & Kemis \\
\hline
\end{tabular}




\begin{tabular}{ccc}
\hline Sukra & Jumuah & Jumuwah \\
\hline Sanaiscara & Sabt & Saptu \\
\hline
\end{tabular}

According to Ronggowarsito, the beginning of the Javanese Islamic calendar began on Saturday Pahing. This refers to the year Sunan Giri II formulated the calendar in the year 1443 Saka. Meanwhile, according to historians, the Javanese Islamic calendar, which Sultan Agung initiated began in 1555 Saka, which was the beginning of the year which fell on Legi Friday. Ronggowarsito explained that the Javanese use a fiveday cycle, which is a typical Javanese day cycle. Based on the calculation of the first day of the month of Muharram, it falls on the kliwon. If the previous year was wastu, then the beginning of Muharram in the year that will take place falls on the fifth day, namely wage. If the year that has passed is a wuntu, then the year that will occur early in Muharram will fall on the same day as the year that has passed. If last year the day was wage early Muharram, then the "pasaran" will also be wage in the year that will take place.

In the calculation of the beginning of each month, if the month is kamal. Then the "pasaran day" of the following month is the same as the previous month. If the date of the month that has passed is kliwon, then the beginning of the following month also falls on the kliwon "pasaran day". If the previous month was nuqus, the "pasaran" for the following month will be delayed by one day. If the date of the month that has passed is kliwon "pasaran day", then the beginning of the following month falls on the wage day, and so on. In the Javanese Islamic calendar there is a cycle of kurup (120 years). Kurup is a cycle that shows that every 120 years there is a reduction of one day. This reduction occurs at the end of the 8-year cycle (windu) where the big month of the 8th year "jimakir", which should be 30 leap days, becomes 29 basitah days. This is because the course of the Moon's rotation is calculated every month to decrease by one minute. It means going back one minute.

Ronggowarsito presents the history of the Javanese Islamic calendar in a different way. In Serat Widya Pradhana, Ronggowarsito did not mention the name of Sultan Agung concerning the Javanese calendar. Ronggowarsito linked the Javanese Islamic calendar with Sunan Giri II, who lived long before Sultan Agung. ${ }^{31}$

${ }^{31}$ Ahmad Musonnif, "GENEAOLOGI KALENDER ISLAM JAWA MENURUT RONGGO WARSITO: Sebuah Komentar Atas Sejarah Kalender Dalam Serat Widya Pradhana," Kontemplasi: Jurnal Ilmu-Ilmu Ushuluddin 5, no. 2 (2017), https://doi.org/10.21274/kontem.2017.5.2.329-355. 


\section{Bugis-Makassar Calender}

The Bugis-Makassar calendar is the same as the Kamariyah calendar. It uses the cycles of the moon as a guideline for timing. However, there are differences in the determination system. The Bugis-Makassar community uses a thin black cloth as a traditional way, better known as "mappabaja". For the Bugis-Makassar people, the circulation of the moon is a natural process that has mythological meaning. This affects the daily activities of the community and is believed to be a "pananrang". The existence of Pananrang is significant for the life of the Bugis-Makassar people. Therefore, pananrang is written in the lontara script, which is the language for all cultural activities of the Bugis-Makassar people, including the calendar in ancient times. ${ }^{32}$

The definition of the lontara script comes from the word "lontar", a tree name used as a medium for writing using "kallang" or stick (pen made of coarse palm fiber). Based on the research results, the lontara script was designed by Daeng Pamatte, the Gowa syahbandar during the Karaeng Tumaparisi Kallonna era (1511-1548) and then perfected by the Bugis. ${ }^{33}$ Until now, lontara is only owned by certain parties and its existence is kept secret.

Most of the Bugis-Makassarese people believe that the naming of days in the cycle of one month comes from an event or experience that is passed down from generation to generation. This happened in BC by the ancestors. Then, summarized in "pangaderreng", an advice that must be held as something that has sacred value.

The ancestors of Bugis-Makassar did not recognize the terms month and year. So when asked them about the origin of the calendar, they will only answer "it's been a long time, it's hard to count (separiayama)". This term has been used until the time when the kingdom of Bone I led South Sulawesi, which ruled for four pariyama or approximately 32 years. During the Bone I kingdom (before the Legend to Manurung), the Bugis people were still influenced by the myths of the La-Galigo era. These tend to bear similarities to Hindu culture and animist beliefs. Evidently, the term separiayama or one pariyama is equal to eight, which has the same thing as one windu, which also means eight years. Even the names and calculations of the days of the week are not seven days but five days. The development of the Bugis-Makassar culture on the calculation of the month or calendar is in line with the history of the entry of Islam in South Sulawesi. This happened around the XVI century during the reign of King of Bone XI, according to historians. This had a significant influence on the Bugis-Makassar culture, including the calendar system which switched to the Hijri calendar system. Although, they are still influenced by the system of their ancestors' inheritance known as "naas seven", namely (1)

\footnotetext{
${ }^{32}$ Syarifuddin Yusmar, "Penanggalan Bugis-Makassar Dalam Penentuan Awal Bulan Kamariah Menurut SyariAh Dan Sains," HUNAFA: Jurnal Studia Islamika 5, no. 3 (2008): 265, https://doi.org/10.24239/jsi.v5i3.175.265-286. (2018): 16.

${ }^{33} \mathrm{Ahmad}$ Musonnif, "Relasi Intelektual, Jawa Islam, Bugis Islam, Dan Turki Utsmani,” Kontemplasi, 0106
} 
night 3, (2) night 5, (3) night 9, (4) night. -16, (5) 21st night, (6) 24th night, and (7) 25th night. This count begins from the appearance of the chamber crescent. ${ }^{34}$

Determining the entry at the beginning of the month is carried out in several ways by the Bugis-Makassar tribe community. These methods include (1) mappalao fuppuesso, that is, when the sun and the moon set together, and after the sun sets, count the inclusion of the beginning of the month; (2) mappabbaja, observes the moon in the east at dawn, before dawn by using a thin black cloth closed over the eyes, and if there is a horizontal line in three layers, it is called tellu teammate which means that in three days there will be a change of months. If there is a double horizontal line, two more days are published at the beginning of the month; and (3) there is lightning or drizzle in the middle of the night before the change of the beginning of the month. The belief of the Bugis-Makassar community regarding the entry of the beginning of the new month is counted sequentially from the 1st to the 30th with the term aoPo aulE (monthly circulation, every date) or ompo.

Tabel 8. Name Date in Bugis

\begin{tabular}{ccccc}
\hline Latin & Date (aoPo aulE $)$ & Bugis $(\mathbf{a E s o})$ & Latin & Meaning \\
\hline 1 & Esid & $\mathrm{Nr}$ & Nyarang & horse \\
\hline 2 & Duw & joG & Jonga & Deer \\
\hline 3 & tElu & Mc & Macang & Tiger \\
\hline 4 & aEp & Milyo & Miyong & Cat \\
\hline 5 & Lim & Suku & Sukku & Even \\
\hline 7 & aEnE & Etdo & Tedong & Buffalo \\
\hline 8 & Pitu & Blwo & Balawo & Mouse \\
\hline 9 & Aruw & Iebi & Lebbi & More \\
\hline 10 & Aesr & Asu & Asu & Dog \\
\hline 11 & sEpulo & Ng & Naga & Dragon \\
\hline 12 & sEpulo sid & Ebeb & Bebe & Dumb \\
\hline 13 & sEpulo duw & Mc & Macang & Tiger \\
\hline 14 & sEpulo tEl & Ng & Naga & Dragon \\
\hline & sEpulo aEp & siG & Singa & Lion \\
\hline
\end{tabular}

${ }^{34}$ Hikmatul Adhiyah Syam, "Harmonisasi Penanggalan Bangsa Arab Dan Suku Bugis-Makassar," Elfalaky 02 (2018): 116-117. 


\begin{tabular}{ccccc}
\hline 15 & sEpulo lim & Jog & Jonga & Deer \\
\hline 16 & sEpulo aEn & Bwi & Bawi & Pig \\
\hline 17 & sEpulo pit & mnu-mnu & Manu-Manu & Birds \\
\hline 18 & sEpulo ar & Wni & Wani & Bee \\
\hline 19 & sEpulo aesr & blipE & Balipeng & Centipede \\
\hline 20 & duw pulo & Alialai & Ali-ali & Tame Animal \\
\hline 21 & duw pulo sidi & aEsai & Assai & True \\
\hline 22 & duw pulo duw & doGi & Dongi & Sparrow \\
\hline 23 & duw pulo tElu & aCel & Ancale & Grasshopper \\
\hline 24 & duw pulo aEp & mlePai & Malampei & Long \\
\hline 25 & duw pulolim & psE & Pase (Taccipi) & All Difficult \\
\hline 26 & duw pulo aEnE & tupGi & Tuppang & Frog \\
\hline 27 & duw pulo pitu & aulEai & Ulei & Caterpillar \\
\hline 28 & duw pulo aruw & Klpu & Kalapang & Turtle \\
\hline 29 & duw pulo aesr & Aiiti & Iti & Duck \\
\hline 30 & tElu pulo & Mnu & Manu & Chicken \\
\hline
\end{tabular}

Initially, the concept of a timing system for the Bugis community had certain aspects related to maritime activities. This is because maritime is the most significant source of livelihood for the coastal Bugis people. Therefore, the concept of determining time is divided into three cycles, namely: annual, lunar and daily cycles. ${ }^{35}$

The annual cycle is a cycle divided into twelve months according to the Gregorian calendar. This cycle is based on two wind seasons as a sign of time.

Tabel 9. The Monsoon Cycle in the Flores Sea

\begin{tabular}{ccc}
\hline Month & Wind Season & Weather and Sea Conditions \\
\hline 10 & & Shady \\
\hline 11 & West & Shady and Pancaroba \\
\hline 12 & West & Pancaroba (transition period) and Rain-Wind \\
\hline
\end{tabular}

${ }^{35}$ Gene Ammarel, Navigasi Bugis, I (Makassar: Ininnawa, 2016)., h. 103. 


\begin{tabular}{ccc}
\hline 1 & West & West Wind Comes, Bringing Heavy Rain and Waves \\
\hline 2 & West & West Wind Comes, Bringing Heavy Rain and Waves \\
\hline 3 & West & The Wind Calms Down; Rain stops \\
\hline 4 & East & $\begin{array}{c}\text { Pancaroba (transition period) } \\
\text { Medium Sized Waves }\end{array}$ \\
\hline $6-8$ & East & The East Wind Comes, Bringing Bright Sky and \\
\hline 9 & East & Strong Winds, Carrying Waves; Ocean Waves appear \\
\hline
\end{tabular}

The lunar cycle is knowledge related to the lunar period. The month of the Bugis community is related to the Islamic calendar (Kamariyah) which uses the synodic period. Attention to this is increasing, especially on Islamic holy days such as the month of Ramadan. Determination of the entry of the beginning of a new month in the Hijriyah calendar is marked by the appearance of the crescent moon at night. Meanwhile, the Bugis people call it séddibenni kétengé which means the first night of the month of Kamariyah. ${ }^{36}$

Table 10. Moon Phase

\begin{tabular}{ccc}
\hline Phase & Indonesia & Moon Age (Day) \\
\hline Kéteng Taccipi & Young Crescent & $1-4$ \\
\hline Kéteng Sippué Maloló & Half Young Moon & $7-8$ \\
\hline Kéteng Genne & Full moon & 15 \\
\hline Kéteng Sippué Matoa & Side Old Moon & $22-23$ \\
\hline Kéteng Cippi-Cippi & Old Crescent & $26-29$ \\
\hline Kéteng Kelleng & Dead Moon & 30 \\
\hline
\end{tabular}

The daily cycle is a system of determining daily times for the Bugis people. This is considered more detailed if it is based on determining the time of prayer (subuh, dzuhur, ashar, magrib, and isya) through the position of sunlight. This is because prayer time is a very common time used by Bugis sailors compared to determining the day in general (morning, noon, evening, and night).

${ }^{36}$ Ammarel., h. 105. 
Tabel 11. Waktu Salat Setempat

\begin{tabular}{ccc}
$\begin{array}{c}\text { Bugis Prayer } \\
\text { Time }\end{array}$ & $\begin{array}{c}\text { Common Prayer } \\
\text { Time }\end{array}$ & The appearance of the sun and its rays \\
\hline Magaribi & $18: 20$ & Sunset \\
\hline Isa & $19: 20$ & $\begin{array}{c}\text { Approximately One Hour After Sunset } \\
\text { Whe Shat Appears for the First Time (At 5:00 } \\
\text { The Shadows Are Clear) }\end{array}$ \\
\hline Lohoro & $04: 20$ & $\begin{array}{c}\text { Shadows Seen Short (At 13:00 Shadows Have } \\
\text { Move Slightly To the Side) }\end{array}$ \\
\hline Assara & $12: 20$ & $\begin{array}{c}\text { The Sun Is Approximately 2 To 3 Ahead Of } \\
\text { The Horizon }\end{array}$ \\
\hline
\end{tabular}

Table 12. Separation of Day and Night of the Bugis Society

\begin{tabular}{ccc}
\hline Period & Indonesian Term & Estimated International Hours \\
\hline Labukesso & Evening, Night & $18: 00-19: 00$ \\
\hline Wenni & Night & $19: 00-03: 00$ \\
\hline Tengngabenni & Mid Night & $24: 00-02: 00$ \\
\hline Denniari & Pre Dawn & $03: 00-04: 30$ \\
\hline Subu & Dawn & $04: 30-06: 00$ \\
\hline Élé & Morning & $06: 00-11: 00$ \\
\hline Esso & Day & $11: 00-15: 00$ \\
\hline Tangngasso & Mid Day & $12: 00-13: 00$ \\
\hline Araweng & Afternoon & $15: 00-18: 00$ \\
\hline
\end{tabular}

All forms of Bugis community activities begin with paying attention to the quality of the time of day. Besides, it also takes into account whether the time is good or not to start an activity. Thus, this determination of good and bad time is born of the terms good days and bad days with certain clues.

For example, Monday (esse Seneng), Sunday (Aha), Wednesday (Araba) dan Friday (Juma) are a good day. Tuesday (Salasa) is a bad day or unlucky day because it has the similarity of the letters of the word with the word sala-sala, sisala, lari sala, which is in Bugis culture is known for 
the sound of death and ugliness. Based on existing research, the Bugis community located in Kendari City uses a system of determining good and bad days with the indication of symbols. These are Arabic writing symbols, Mathematical symbols, handwritten symbols, Bugis lontara symbols, Bugis lontara symbols and pictures, Soewandi script symbols, animal symbols, star symbols, flag symbols, H. David symbols, and $\mathrm{Hj}$ symbols. Nursia. ${ }^{37}$

The Bugis-Makassar people also use kutika in determining the day. Kutika is a book that in general contains predictions about unlucky days, dates, and months written using lontara and jawi characters in the Bugis or Makassar languages. The use of the jawi Arabic script cannot be separated from the influence of Islam that entered Gowa. It is said that the writing of this manuscript was the role of a prominent figure in the history of the Gowa kingdom. Daeng Pamatte as a government official who at that time began to introduce the lontara script as the official language of the Gowa kingdom and Karaeng Pattingalloang as an intellectual figure who gave full attention to the development of science around the XV century.

Historically, the terms good and bad days refer to the results of the analysis of the events that have continued with each other over a long period. Then, it is recorded so that it can serve as a guide for the community and future generations. The contents of the manuscript indicate the calendar day in the Hijri year is interpreted as follows: "Iyaminne Pappasanna Tau Towata Massing Nijarreki. Tallasa'na Allo Tujua: Sanneng; Itimboro Irayai Katallassannai Anginga, Salasa; Iraya Lebbaki Katallassannai Bintoenga, Araba; Iyara' Lebbaki Katallasannai Pepeka, Kammisi; Iraya Lebbaki Katallasannai Bulanga, Juma'; Ilau Lebbaki Katallassannai Alloa, Sattu; Ilau Iyaraki Katallasannai Buttaya, Aha'; Itimboro Lebbaki Katallassannai Je'neka. Lowana Bulanga: Muharrang; Allo Aha', Sappara'; Allo Araba, Rabbele' Awwala'; Allo Juma', Rabbele' Ahere'; Allo Salasa, Jumadele' Awwala'; Allo Kammisi', Jumadele' Ahere'; Allo Sattu, Rajja'; Allo Juma', Sabang; Allo Kammisi', Rumallang; Allo Salasa Sawwala' Allo Sattu, Julukaeddah; Allo Sanneng, Juluhijjah; Allo Araba. Nakasa Pingngappaka Sibulang: Juma' Uru-urunaya, Sattu Makapinruanna, Aha' Makapintallunna, Sanneng Makapingngappa'na".

Meaning: "These are the messages of our ancestors that must be guided. The birth of the universe for seven days. Monday, the wind began to blow from the south to the north. Tuesday, the eastern part of the star came into view. Wednesday, on the eastern horizon, the fire started. Thursday, on the eastern horizon, the moon begins to shine. Friday, in the western part of the day began to be created. Saturday, in the western part of the land began to be created. Sunday, from the south the water began to gush in all directions. Some days need to be avoided when doing activities, namely in the month of Muharram; fell the first Sunday, on Safar; falls on the

${ }^{37}$ Fahmi Gunawan, "Symbol Guidelines of Good and Bad Days of Bugis Community in Kendari," Patanjala Vol. 10, no. 3 (2018): 435-54. 
first Wednesday, on Rabiul Awal; falls on the first Friday, on Rabiul Akhir; falls on the first Tuesday, on Jumadil Awal; falls on the first Thursday, on Jumadil Akhir; falls on the first Saturday, on Rajab; falls on the first Friday, in the month of Shabban; fall on the first Thursday, in Ramadan; falls on the first Tuesday, on Shawwal; falls on the first Saturday, on Dzulkaedah, falls on the first Monday, on Dzulhijjah, falls on the first Wednesday. (every one month, consisting of four weeks) in every first week, there are unlucky days: Friday in the first month, Saturday in the second month, Sunday in the third month, and Monday in the fourth month". ${ }^{38}$

The Bugis-Makassar people still sacred the names of the days as pananrang used as guidelines for all actions by seeking quality time. In this case, it is stated that in one week there are five days which have their own quality in each time.

Table 13. Quality of the Day of the Bugis Community Week

\begin{tabular}{cccccc}
\hline Name of Day & $\begin{array}{c}\text { Ele } \\
\text { (Morning) }\end{array}$ & Abbuweng & $\begin{array}{c}\text { Tangasso } \\
\text { (Mid Day) }\end{array}$ & Lesang Esso & $\begin{array}{c}\text { Araweng } \\
\text { (Afternoon) }\end{array}$ \\
\hline Friday (Pong) & Mate (Dead) & Tuwo (Life) & $\begin{array}{c}\text { Maddara } \\
\text { (Bleeding) }\end{array}$ & $\begin{array}{c}\text { Lobbang } \\
\text { (Empty) }\end{array}$ & $\begin{array}{c}\text { Mallise } \\
\text { (Contain) }\end{array}$ \\
\hline $\begin{array}{c}\text { Saturday } \\
\text { (Bisaka) }\end{array}$ & $\begin{array}{c}\text { Maddara } \\
\text { (Bleeding) }\end{array}$ & Tuwo (Life) & Mate (Dead) & $\begin{array}{c}\text { Mallise } \\
\text { (Contain) }\end{array}$ & $\begin{array}{c}\text { Lobbang } \\
\text { (Empty) }\end{array}$ \\
\hline $\begin{array}{c}\text { Sunday } \\
\text { (Soga) }\end{array}$ & $\begin{array}{c}\text { Mallise } \\
\text { (Contain) }\end{array}$ & Mate (Dead) & Tuwo (Life) & $\begin{array}{c}\text { Maddara } \\
\text { (Bleeding) }\end{array}$ & $\begin{array}{c}\text { Lobbang } \\
\text { (Empty) }\end{array}$ \\
\hline $\begin{array}{c}\text { Monday } \\
\text { (Tellettu) }\end{array}$ & $\begin{array}{c}\text { Lobbang } \\
\text { (Empty) }\end{array}$ & Tuwo (Life) & $\begin{array}{c}\text { Maddara } \\
\text { (Bleeding) }\end{array}$ & $\begin{array}{c}\text { Mallise } \\
\text { (Contain) }\end{array}$ & Mate (Dead) \\
\hline $\begin{array}{c}\text { Tuesday } \\
\text { (Wunga- } \\
\text { wunga) }\end{array}$ & $\begin{array}{c}\text { Mallise } \\
\text { (Contain) }\end{array}$ & Mate (Dead) & $\begin{array}{c}\text { Lobbang } \\
\text { (Empty) }\end{array}$ & Tuwo (Life) & $\begin{array}{c}\text { Maddara } \\
\text { (Bleeding) }\end{array}$ \\
\hline $\begin{array}{c}\text { Wednesday } \\
\text { (Tepati) }\end{array}$ & Mate (Dead) & Tuwo (Life) & $\begin{array}{c}\text { Maddara } \\
\text { (Bleeding) }\end{array}$ & $\begin{array}{c}\text { Lobbang } \\
\text { (Empty) }\end{array}$ & $\begin{array}{c}\text { Mallise } \\
\text { (Contain) }\end{array}$ \\
\hline $\begin{array}{c}\text { Thursday } \\
\text { (Tanra } \\
\text { Wallu) }\end{array}$ & $\begin{array}{c}\text { Mallise } \\
\text { (Contain) }\end{array}$ & $\begin{array}{c}\text { Lobbang } \\
\text { (Empty) }\end{array}$ & Mate (Dead) & Tuwo (Life) & $\begin{array}{c}\text { Maddara } \\
\text { (Bleeding) }\end{array}$ \\
\hline
\end{tabular}

Meanwhile, in Lontara Pangisengeng, which is based on the contents of the lontara, mostly contains the traditional knowledge system that exists in the local community, it is stated that ${ }^{39}$ :

\footnotetext{
${ }^{38 Z}$ Zulkifli Mappadomba, “Orang Bugis Makassar Dan Astrologinya Dalam Kutika,” Etnis.Id, 2020, https://etnis.id/orang-bugis-makassar-dan-astrologinya-dalam-kutika/. n.d., 8 .

${ }^{39}$ Departemen Pendidikan and Kebudayaan, "Sulawesi Selatan Lontarak Pangissengeng Daerah," Buku,
} 
"Rekko muharrang ngi na siamek uleng nge/ma ega jak na paturung Allah Taala ri tana e/Ma ega to sara ininnawa na arung nge/Enreng nge tau tebbek na/Ma deceng ngik massidekka ro to namase-mase". Meaning: If the lunar eclipse occurs in the month of Muharram, many crimes are sent down by Allah Taala / in the country. Lots of calamities befall the rulers and their people. Better, to avoid this we increase the donation to the poor. ${ }^{40}$

\section{Maluku Society Calender}

Maluku is known as the Thousand Islands. Maluku is also categorized as an archipelago province with $92.4 \%$ sea area and $7.5 \%$ land area of its total area. In other words, the Maluku sea area is about 12 times its land area. ${ }^{41}$ Based on these data, the people of Saparua Island have a dating system related to waters, specifically in the form of a traditional boat making process. Saparua Island is a small island in the Central Maluku region, about 50 miles from Ambon, the capital city of Maluku.

The people of Saparua Island specifically use ancient astronomical calculations to build traditional boats. This ancient astronomical calculation system is known as tanoar (calculation of good times or days) which is enshrined in a guidebook, namely nats. Nats are written by hand. In the book, there are time standards based on the type of animal, moon and stars. This book is a guide and is owned by every boat builder.

Research shows that the Saparua people have certain astrological calculations when making traditional boats by counting the number of full moons. Tanoar is done when choosing wood for the boat. Astronomical calculations are made based on the full moon, namely the number of times the moon is light and the number of times the moon is dark. Based on these calculations, it can be seen the strength of the wood used to make boats. If the wood is taken at the wrong month, the wood will be eaten by termites. However, it is necessary to use wood from special trees planted by the local community. ${ }^{42}$

Meanwhile in Negeri Soya, tanoar is used in determining the timing of the implementation of the Cuci Negeri. Negeri (typical Ambonese-Maluku Tengah term for village) Soya is in the Sirimau sub-district, Ambon City, Maluku Province. Geographically, it is located in the mountainous region of Sirimau with an altitude of about 464 meters above sea level, about $6 \mathrm{~km}$ from the center of Ambon City. Negeri Soya correlates with the Soya kingdom in the past, which was the forerunner to the birth of Ambon City. This is because Negeri Soya is one of the oldest customary government areas in Ambon and Maluku.

${ }^{40}$ M. Pabbajah, "Religiusitas Dan Kepercayaan Masyarakat Bugis-Makassar,” Al-Ulum: Jurnal Studi Islam 12, no. 2 (2012): 397-418.

${ }^{41}$ Reny H. Nendissa, "Eksistensi Lembaga Adat Dalam Pelaksanaan Hukum Sasi Laut Di Maluku Tengah," Jurnal Sasi 16, no. 4 (2010): 1-6.

${ }^{42}$ Butar-Butar, Astronomi., h. 48-49. 
Cuci Negeri Soya tradition is a phenomenal tradition common among the people of Maluku and especially the people of Ambon. This is proven by the establishment of Cuci Negeri Soya customs as an Intangible Cultural Heritage by the government of the Republic of Indonesia through the Ministry of Culture and Tourism, on 20 October 2015. Through its 12 stages, Cuci Negeri Soya tradition is carried out by articulating various expressions of cultural order. Examples include their traditional ritual practices, the symbols they use, the underlying myths, musical performance, dance, language and food, to the hybrid religiosity that colors them. As a fact, the encounter between adatist beliefs and beliefs of modern religions, especially Christianity. ${ }^{43}$ This tradition is carried out in places that are considered sacred by the local community, one of which is in certain locations around Mount Sirimau.

This tradition has a background story related to the myth of a dragon that swallows youth. Then, regurgitated it after five days in the stomach of the dragon. With the essence as renewal, the process of circulation of life requires cleansing oneself from the environment. As Roland Barthes suggests that myth is a form of message (signification method). Furthermore, this is part of the communication system, which wraps a meaning in a sign system, in the form of stories, pictures, writings, etc. ${ }^{44}$

As an ancestral heritage that has the meaning of customary beliefs, influences life, and various other considerations, Cuci Negeri also gives new meaning to the choice of time itself. In selecting tanoar, or the Soya people also call it the term kotika, it is interpreted as hari bae, which means a good day. So the timing for the implementation of the Cuci Negeri will take place once a year and always fall on the first and second week of December in each current year. This timing is influenced by the traditional belief view of the time, which coincides with the momentum of the arrival of the west (wind) season that occurs from early December to March.

It is believed that the arrival of the west wind is the momentum of the presence of the ancestors, which is the main prerequisite for implementing the Cuci Negeri. Because it is realized that the Cuci Negeri could not be done without the presence of the ancestors. Apart from these considerations, according to Soya's parents, there are two other reasons behind the choice of time to carry out the Cuci Negeri in Soya, namely: (1) considering the eastern season, which was marked by the arrival of the rainy season in previous months, the environmental situation in Soya's country. badly in need of repair; (2) the aftermath of Christianity (1500s) was one consideration.

\footnotetext{
${ }^{43}$ Ferry Nahusona, Tradisi Dan Kebudayaan Nusantara (Semarang: Lembaga Studi Sosial dan Agama (eLSA)Press, 2019)., h. 2.

44TRIESKA SELA PRATIWI, "Analisis Semiotika Roland Barthes Terhadap Logo Calais Tea” 2, no. 3 (2015): 108, https://openlibrary.telkomuniversity.ac.id/home/catalog/id/104472/slug/analisis-semiotika-rolandbarthes-terhadap-logo-calais-tea.html\%0Ahttps://core.ac.uk/download/pdf/299904072.pdf.
}

Al-Hilal: Journal of Islamic Astronomy, Vol. 3, No. 1, 2021

p-ISSN : 2775-1236 ; e-ISSN : 2775-2119 
In this way, the Soya community, who are members of the local church, have made the Cuci Negeri as a part of the Soya people's readiness to make improvements and clean up the environment, both to God the Creator, as well as in relationships between personal and Soya residents. ${ }^{45}$

\section{Conclusion}

The emergence of calendars in each region in the archipelago has its respective functions and meanings. It all depends on how the calendar user treats and interprets the calendar. In Batak, people interpret the calendar to determine good and bad days. In Java, the Pranatamangsa calendar is interpreted as a marker of the season for farming. The Saka calendar is considered a marker of religious rituals.

Meanwhile, the Javanese Islamic calendar is used as a memorial to the history and teachings of Islam. Besides, in the Bugis Makassar community, some calendars have specific mythological meanings. And among the people of Maluku, there is their calendar used to mark the time of making boats.

\section{E. Bibliography}

Ammarel, Gene. Navigasi Bugis. I. Makassar: Ininnawa, 2016.

Asy Syarifain, Khadim Al Haramain. Al-Quran Dan Terjemahnya. Jakarta, 1971.

Azhari, Susiknan, and Ibnor Azli Ibrahim. "Kalender Jawa Islam: Memadukan Tradisi Dan Tuntutan Syari." Jurna Asy-Syirah 42, no. 1 (2008).

Budiwati, Anisah, "Historical Astronomic Provision of Birth and Death Prophet Muhammad SAW," Al-Hilal:Journal of Islamic Astronomy 1 (2019)

Butar-Butar, Arwin Juli Rakhmadi. Astronomi. Surabaya: Media Sahabat Cendekia, 2019.

Farichah, Faiz, "The Java Calendar and Its Relevance with The Islamic Calendar," AlHilal:Journal of Islamic Astronomy 2 (2020).

Gunawan, Fahmi. "Symbol Guidelines of Good and Bad Days of Bugis Community in Kendari.” Patanjala Vol. 10, no. 3 (2018).

Halimah, Siti Nur. “Al-Marshad: Jurnal Astronomi Islam Dan Ilmu-Ilmu Berkaitan.” Jurnal Astronomi Islam Dan Ilmu-Ilmu Berkaitan 4, no. 1 June (2018): 11. https://media.neliti.com/media/publications/268350-penanggalan-mesir-kuno61e38fac.pdf.

Ilyas, Pemikiran Mohammad, Amri Fakultas Syari, Hukum Uin, Walisongo Semarang, Hamka Kampus, and I I I Ngaliyan. "PEMIKIRAN MOHAMMAD ILYAS TENTANG PENYATUAN," n.d., 1-15.

Istiqamah, Iva. "Prasasti Masjid Agung Sunan Ampel Surabaya (Study Tentang Kontak Peradaban Antara Jawa, Arab Dan Barat Dalam Kronologi.” Sunan Ampel Surabaya, 2009.

${ }^{45}$ Nahusona, Tradisi Dan Kebudayaan Nusantara., h. 6. 
Lu'ayyin and M. Ihtirozun Ni'am, "Ayyam Al-Bid Syar'i and Astronomy Perspective," AlHilal:Journal of Islamic Astronomy 2 (2020)

Mappadomba, Zulkifli. “Orang Bugis Makassar Dan Astrologinya Dalam Kutika.” Etnis.Id, 2020. https://etnis.id/orang-bugis-makassar-dan-astrologinya-dalam-kutika/.

Masud, Ali. "Penentuan Bulan Kamariah Menggunakan Sistem Aboge Dan Implementasinya.” IAIN Walisongo, 2014. http://eprints.walisongo.ac.id/id/eprint/2748.

Melacak, Sakirman, and Konstruksi Metodologi. "Sakirman Melacak Konstruksi Metodologi...” 4, no. 01 (2015).

Mufadzilah, Ahmad Syafii. “Tarekat Dan Tradisi Lokal.” UIN Sunan Kalijaga, 2019.

Musonnif, Ahmad. "GENEAOLOGI KALENDER ISLAM JAWA MENURUT RONGGO WARSITO: Sebuah Komentar Atas Sejarah Kalender Dalam Serat Widya Pradhana.” Kontemplasi: Jurnal Ilmu-Ilmu Ushuluddin 5, no. 2 (2017). https://doi.org/10.21274/kontem.2017.5.2.329-355.

-. "Relasi Intelektual, Jawa Islam, Bugis Islam, Dan Turki Utsmani." Kontemplasi, 0106 (2018): 16.

Mustaid, Ahmad. "Analisis Penanggalan Jawa Pranata Mangsa Terhadap Sirkulasi Monsun Dalam Perspektif Klimatologi.” UIN Walisongo Semarang, 2019.

Nahusona, Ferry. Tradisi Dan Kebudayaan Nusantara. Semarang: Lembaga Studi Sosial dan Agama (eLSA)Press, 2019.

Nasional, Departemen Pendidikan. "Kamus Besar Bahasa Inddonesia Pusat Bahasa." In KBBI, edited by Dendy Sugono, IV., 1396. Jakarta: PT Gramedia Pustaka Utama, 2011.

Nadirin, Akhmad and M. Ihtirozun Ni'am, "Date Correction of Omar Bin Khattab's Death in an Astronomical Perspective," Al-Hilal:Journal of Islamic Astronomy 1 (2019)

Nendissa, Reny H. "Eksistensi Lembaga Adat Dalam Pelaksanaan Hukum Sasi Laut Di Maluku Tengah.” Jurnal Sasi 16, no. 4 (2010).

Pabbajah, M. "Religiusitas Dan Kepercayaan Masyarakat Bugis- Makassar.” Al-Ulum: Jurnal Studi Islam 12, no. 2 (2012).

Pemikiran, Jurnal, and Hukum Islam. “Al-Mizan” 13, no. 1 (2017).

Pendidikan, Departemen, and Kebudayaan. "Sulawesi Selatan Lontarak Pangissengeng Daerah.” Buku, n.d.

PRATIWI, TRIESKA SELA. "Analisis Semiotika Roland Barthes Terhadap Logo Calais $\begin{array}{lllll}\text { Tea” } 2, & \text { no. } & 3 & \text { (2015): } & 108 .\end{array}$ https://openlibrary.telkomuniversity.ac.id/home/catalog/id/104472/slug/analisissemiotika-roland-barthes-terhadap-logo-calaistea.html\%0Ahttps://core.ac.uk/download/pdf/299904072.pdf.

Ridhallah, Alaik. "Sistem Penaggalan Baha i Persfektif Astronomi." AL-AFAQ Jurnal Ilmu Falak Dan Astronomi 2, no. 1 (2020). 
Rosalina, Irma. "Penyesuaian Kalender Saka Dengan Kalender Hijriyah Dan Aplikasinya Dalam Penentuan Awal Bulan Qomariah.” Fakultas Syariah UIN Maulana Malik Ibrahim Malang. November 19, 2013.

Rufaidah. "Sistem Perhitungan Kalender Jawa Islam Dalam Kehidupan Masyarakat Desa Tunglur, Kec. Badas, Kab. Kediri.” UIN Sunan Amel, 2015.

Sobirin, Supardiyono. “Pranata Mangsa Dan Budaya Kearifan Lingkungan.” Jurnal Budaya Nusantara 2, no. 1 (2018). https://doi.org/10.36456/b.nusantara.vol2.no1.a1719.

Syam, Hikmatul Adhiyah. "Harmonisasi Penanggalan Bangsa Arab Dan Suku BugisMakassar.” Elfalaky 02 (2018).

Wiriadiwangsa, Dedik. "Pranata Mangsa, Masih Penting Untuk Pertanian,” n.d.

Yuli, Hastin Erma. "Mengapa Terjadi Kemarau Basah?” Membumi Mengangkasa. 2013. https://doi.org/https://yulihastin.wordpress.com/2013/07/03/mengapa-terjadimusim-kemarau/.

Yusmar, Syarifuddin. "Penanggalan Bugis-Makassar Dalam Penentuan Awal Bulan Kamariah Menurut SyariAh Dan Sains.” HUNAFA: Jurnal Studia Islamika 5, no. 3 (2008). https://doi.org/10.24239/jsi.v5i3.175.265-286. 
Al-Hilal: Journal of Islamic Astronomy, Vol. 3, No. 1, 2021

p-ISSN : 2775-1236 ; e-ISSN : 2775-2119 